Ege Tıp Dergisi / Ege Journal of Medicine 2017;56(2):77-81

\title{
Deneysel diabet modeli oluşturulan farelerde tirozin kinaz inhibitör uygulanımının testis dokusu üzerine olan etkilerinin pluripotensi kapasitesi ve hücre adezyonu özelinde araştırıması
}

The investigation of effects of tyrosine kinase inhibitor on testicular tissue in terms of pluripotent capacity and cell adhesion in experimental diabetic mice

\author{
Kaan Özdedeli ${ }^{1} \quad$ Hüseyin Aktuğ ${ }^{2} \quad$ Fatih Oltulu $^{2} \quad$ Gülperi Öktem ${ }^{2} \quad$ Altuğ Yavaşoğlu ${ }^{2}$ \\ Eda Açıkgöz ${ }^{3} \quad$ Gürkan Yiğittürk $^{2} \quad$ Kenan Demir $^{2} \quad$ Ayşegül Uysal ${ }^{2}$ \\ ${ }^{1}$ Trakya Üniversitesi Tıp Fakültesi, Üroloji Anabilim Dalı, Edirne, Türkiye \\ ${ }^{2}$ Ege Üniversitesi Tıp Fakültesi, Histoloji ve Embriyoloji Anabilim Dalı, İzmir, Türkiye \\ ${ }^{3}$ Yüzüncüyıl Üniversitesi Tıp Fakültesi, Histoloji ve Embriyoloji Anabilim Dalı, Van, Türkiye
}

\section{Öz}

Amaç: Tirozin kinaz inhibisyonunun diyabet etkisi altındaki testis dokusu üzerine göstereceği etkileri araştırmaktır.

Gereç ve Yöntem: Çalışmamızda 31 adet CD1 türü erkek fare kullanıldı ve dört gruba ayrılı: Grup 1'de (kontrol grubu) 7, Grup 2'de tirozin kinaz inhibitörü uygulanan 7, Grup 3'te diyabetik ve SF uygulanan 8, Grup 4'te diyabet + tirozin kinaz inhibitörü uygulanan 9 denek hayvanı yer aldı. Grup 1'de herhangi bir uygulama yapılmadı. Grup 2'deki farelere 3 hafta boyunca tirozin kinaz inhibitörü verildi. Diyabet oluşturulması için $0.1 \mathrm{~mol} / \mathrm{L}$ tek doz streptozotosinin intraperitoneal olarak verildi. $250 \mathrm{mg} / \mathrm{dL}$ ve üzeri kan glikoz seviyesi diyabetik olarak kabul edildi. Deneysel diyabet modeli oluşturulan farelere 1 hafta beklendikten sonra, Grup 3'e SF, Grup 4'e 3 hafta boyunca tirozin kinaz inhibitörü verildi. Sonunda tüm denek hayvanları anestezi altında sakrifiye edilerek histopatolojik inceleme için testis dokuları alındı. İstatistiksel analiz için tek yönlü varyans analizi (ANOVA) testi yapıldı, 0.05’ten küçük p değerleri, istatistiksel olarak anlamlı kabul edildi.

Bulgular: Testis dokusu histopatolojik olarak incelendiğinde deneysel diyabete bağlı olarak seminifer tübülün germ hücre serilerinde kayıp, hücre bütünlüklerinde ise bozulma saptandı.

Sonuç: Bu çalışma, diyabetin testiste germ hücre serilerinde sayısal olarak azalmaya ve hücre adezyon mekanizmasında bozulmaya yol açtığını göstermektedir. Tirozin kinaz inhibitörü uygulamasının, bu hasarlanmada tamir edici etkisinin olduğu düşünülmektedir. Bu hasarın tedavisinin derecesi, uygulanan tirozin kinaz inhibitörünün dozu ve süresine bağlı olarak farklılık gösterebilmektedir. Ancak, klinik diyabet uygulamalarında tirozin kinaz inhibitörü kullanılabilmesi için bu konuda moleküler çalışma sayılarının artışına ihtiyaç vardır.

Anahtar Sözcükler: Tirozin kinaz inhibisyonu, diyabetes mellitus, testis, deneysel çalışma.

\begin{abstract}
Aim: The aim of the study is to investigate the effects of tyrosine kinase inhibition on testicular tissue under the effects of diabetes mellitus.

Materials and Methods:. Thirty one CD-1 male mice were divided into four groups: Group 1 (control group) consited 7, Group 2 (tyrosine kinase inhibitor given group) 7, Group 3 (diabetic group treated with SF) 8 and Group 4 (diabetic group treated with tyrosine kinase inhibitor) 9 experimental mice. No application was made to the animals in Group 1. In Group 2, mice were given tyrosine kinase inhibitor for 3 weeks. Diabetes was induced by intraperitoneal injection of single dose of streptozotocin $0.1 \mathrm{~mol} / \mathrm{L}$. Mice with $250 \mathrm{mg} / \mathrm{dL}$ and higher blood glucose levels were accepted as diabetic. After waiting for 1 week, experimental diabetic mice in Group 3 were treated with SF and those in Group 4 were treated with tyrosine kinase inhibitor for 3 weeks. Then, all the experimental animals were sacrified and the testicular tissue was removed for histopathological examination. The one-way analysis of variance (ANOVA) is used for statistical analysis, a $p$ value less than 0.05 was considered statistically significant.
\end{abstract}

Yazışma Adresi: Fatih Oltulu

Ege Üniversitesi Tıp Fakültesi, Histoloji ve Embriyoloji Anabilim

Dalı, İzmir, Türkiye

Makalenin Geliş Tarihi: 19.01.2016 Kabul Tarihi: 27.07.2016 
Results: Histopathologic examination of the testes revealed loss of germ cells series in the seminiferous tubules and deterioration in cellular integrity depending on experimental diabetes.

Conclusion: By the study, it was demonstrated that diabetes lead to a decrease in the number of germ cells in testes and deterioration in cell adhesion mechanism. The administration of tyrosine kinase inhibitor could be considered to have a regenerative effect in this damage. The degree of treatment of this injury varies depending to the dose and time of the tyrosine kinase inhibitors. But, for the use of tyrosine kinase inhibitors in clinical practice of diabetes mellitus, more molecular studies are needed.

Keywords: Tyrosine kinase inhibition, diyabetes mellitus, testis, experimental study.

\section{Giriş}

Diyabetes mellitus, kandaki glikoz seviyesinin düşmesi ile karakterize edilmiş bir grup metabolik hastalıktır (1).Yüksek hasta sayısı ve hastalığın sonuçları birçok araştırmacıyı yüksek masraflı birçok tedavi geliştirme sürecine itmiştir. Diyabetin en sık karşılaşılan sonucu reaktif oksijen partiküllerinin (ROS) üretilmesidir (2). ROS, $\beta$-hücrelerinin yetmezliğine neden olurken insülin direncinin gelişmesini tetikler (3). Öte taraftan diyabet oksidatif stres yaratmasıyla direk olarak erkek infertilitesini de etkiler. Subfertilite yaygınlık oranı diyabetik hastalarda yüksektir (4). Diyabetin sperm sayısı, kalitesi ve fonksiyonunu negatif bir şekilde değiştirdiği de yapılan çalışmalarla kanıtlanmıştır (5). Erkek fertilitesini (örneğin ejekülasyon, spermatogenezde endokrin kontrolü, ereksiyon, semen hacmi, spermatozoa canlılık ve hareketi gibi) birçok seviyede negatif olarak etkiler (6). Temel işlevi erkek üreme hücreleri, spermatozoaları oluşturmak olan testisler, bireye erkeklik özelliklerini kazandıran testesteron üretir (7).

Tirozin kinaz (TK), protein fosforilasyonunu sağlayan protein kinaz ailesine mensup bir enzimdir. Kinazlar yoluyla proteinlerin fosforilasyonu, sinyal iletim mekanizmasında önemli rol oynar. Sinyal iletimi hücrelerin çoğalması ve apoptozisi gibi işlevleri kontrol ettiğinden, burada meydana gelen değişimler kanser gelişiminde ve metastazlarda önemli rol oynar. TK'lar bulundukları yere göre 2 gruba ayrılır; membran yerleşimli (reseptör) ve sitoplazmik yerleşimli (non-reseptör). Membranda yerleşenlere reseptör tirozin kinazlar (RTK) denir. Bu reseptörler arasında insülin reseptörü, büyüme faktörleri reseptörleri ve efrin reseptörleri örnek gösterilebilir (8). Bilinen yaklaşık 2000 kinaz arasında, 90'dan fazla TK insan genomunda bulunmaktadır. Bunların hücresel aktivitelerde (büyüme, diferensiyasyon, metabolizma, adezyon, motilite, ölüm vs.) önemli rolü vardır. Birçok RTK, gen mutasyonu veya kromozom translokasyonu nedeniyle değişime uğrayarak kanser gelişimde etkin rol oynar. Bu patolojik durum kısaca aşırı-ekspresyon olarak da tanımlanabilir (9).

Cadherinler, büyük bir transmembran ailesini ya da membrana bağlı glikoproteinleri içermektedir ve $\mathrm{Ca}^{+2}$ ye

bağıı olarak özel hücre-hücre bağlantılarını sağlayıp birçok organın morfogenezinde anahtar molekül olarak görev alırlar. Cadherin ailesi en az beş ana alt aileyi içerir, bunlardan e-cadherin, tip I cadherin olarak bilinir ve erken tanınması ve karakterizasyonu ile normal ve patolojik durumlarda gözlemlendiği için bütün cadherinlerin prototipi olarak düşünülür. Tümör baskılayıcı gen ürünü $e$ cadherinler ile cadherin ve aktin filamentlerini bağlayan alt kaplama proteinleri kateninler epitel hücrelerinin yapışma bölgelerinde yoğunlaşır ve sıkı hücre-hücre bağlantılar oluştururlar. Kanser hücrelerindeki hücresel yapışma sisteminde e-cadherinler birçok mekanizma ile inaktif edilirler ve bu durum hem morfolojik hem de biyolojik olarak tümör karakteristikliğini yansıtır. Yaygın infiltre kanserlerde, e-cadherin ile alfa ve beta katenin genlerinde mutasyonlar bulunur. Kanser invazyonu öncesinde, $e$ cadherin hücre yapışma sistemi onkogen ürünü olan cerbB-2 proteini tarafından beta katenine direk bağlanarak tirozin fosforilasyonu ile inaktive edilir. In vivo ve in vitro deney sonuçlarından etkileyici bulgular gösteriyor ki $e$ cadherin/katenin kompleksi invazyon baskılayıcı olarak çalışmaktadır (10).

Temel embriyonik kök hücre transkripsiyon faktörleri SSEA-1 (aşamaya özgü embriyonik antijen 1) kemirgen pluripotent kök hücreler için işaretleyicidir. Bu işaret preimplantasyon embriyodaki hücre yapışması ve hareketinde önemli rol oynar. FUT4 (fukoziltransferaz 4) ve FUT9 tarafından sentezlenir. SSEA-1, yüksek moleküler ağırlıklı (>200 kDa) bir glikoproteindir ve erken fare embriyosunun, fare embriyonel karsinomunun, embriyonik kök hücrelerin ve fare ve insan embriyonik germ hücrelerinin yüzeyinde bulunur. SSEA-1, farklanmamış insan embriyonel karsinomda, embriyonik kök hücrede veya indüklemiş pluripotent kök hücrede; ya da resus maymun embriyonik kök hücre hattında ifadelenmez. Kemirgen embriyonik kök hücrelerinde farklılaşmaya bağlı olarak ifadelenme azalmakta, fakat insanlarda farklılaşma sürecinde ifadelenme artmaktadır. SSEA-1, ayrıca CD15'in ifadelendiği olgun insan granülositinde ve monositinde de bulunur ve yapılan çeşitli çalışmalarda SSEA-1'in hücre yapışması, migrasyon ve hücre farklılaşması olaylarında görev aldığı belirtilmiştir (11).

TK inhibisyonunun diyabet etkisi altındaki testis dokusu üzerine göstereceği etkilerin araştırıması çalışmamızın temel amacını oluşturmaktadır. 


\section{Gereç ve Yöntem}

\section{Deney Kurgulanması - In Vivo Uygulamalar}

$\mathrm{Bu}$ çalışma protokolü Avrupa Birliği'nin deney hayvanları kullanım kurallarına uygundur. Bütün çalışmalar Ege Üniversitesi Hayvan Deneyleri Yerel Etik Kurulu tarafından desteklenmiştir.

Çalışmamızda 31 Adet CD1 Türü erkek fare kullanıldı. Fareler, 4 gruba ayrıldı: Grup 1 (kontrol grubu) 7, Grup 2 (TK inhibitörü uygulanan) 7, Grup 3 (diyabet + SF uygulanan) 8, Grup 4 (diyabet + TK inhibitörü uygulanan) 9 denek hayvanı içermekteydi.

Grup 1'dekifarelere herhangi bir uygulama yapılmadı. Grup 2'de 3 hafta boyunca tirozin kinaz inhibitörü 0.5 $\mathrm{mL} ; 1.5 \mathrm{mgr} / \mathrm{kg}$ verildi. Deneysel diyabet oluşturulması için $0.1 \mathrm{~mol} / \mathrm{L}$ sodyum sitrat tamponu içerisinde çözülmüş streptozotosin (STZ) $55 \mathrm{mg} / \mathrm{kg}$ olacak şekilde tek doz intraperitoneal enjeksiyon yapıldı (12). STZ'nin verilmesinden sonraki 24 . ve 48 . saatlerde tüm hayvanlarda kuyruk kan damarı glikoz seviyesi ölçüldü. $250 \mathrm{mg} / \mathrm{dL}$ ve üzeri kan glikoz seviyesi diyabet olarak kabul edildi. Deneysel diyabet modeli oluşturulan fareler 1 hafta beklendikten sonra, Grup 3'e SF, Grup 4'e TK inhibitörü 3 hafta boyunca $0.5 \mathrm{~mL} ; 1.5 \mathrm{mg} / \mathrm{kg}$ dozunda verildi. Takiben, tüm fareler yüksek doz anestezi altında sakrifiye edilerek testis dokuları rutin histopatolojik inceleme için çıkarıldı.

\section{Immünohistokimyasal İnceleme}

Çıkarılan testisler, \%4'lük paraformaldehit içerisinde gece boyunca bekletilerek tespit edildi, sonra dehidrate edildi, parafine gömüldü ve mikrotom (Leica RM 2145) aracılığı ile kesildi. İmmünohistokimyasal analizler için $0.5 \mu \mathrm{m}$ kalınlığındaki kesitler kullanıldı. Rehidratasyon her biri için 2 dakika süreyle, sıralı $\% 100, \% 95, \% 80$ ve $\% 70$ 'lik alkol serisi ile yapıldı. Kesitler 5 dakika boyunca distile suda bırakıldıktan sonra, endojen peroksidaz aktivitesi \%3'lük $\mathrm{H}_{2} \mathrm{O}_{2}$ içerisinde 20 dakika boyunca inkübe edilerek engellendi. Lam üzerindeki bu doku örneklerinin etrafı işaretleyici bir kalem (Dakopen, Glostrup, Denmark) ile çizildi, fosfat tamponlu salin (PBS) içerisinde 10 dakika boyunca yıkandı, daha sonra $37^{\circ} \mathrm{C}$ 'de 50mM Tris tamponu içindeki \%2'lik tripsinde 15 dakika bırakıldı ve tekrar PBS ile yıkandı. Spesifik olmayan arka plan boyamaları azaltmak için, lamlar \%3'lük bovine serum albümin/1X-Tris tamponlu salin içerisinde 30 dakika boyunca oda sıcaklığında inkübe edildi. Primer antikorlar, e-cadherin ve SSEA-1 (Abcam), 1/200 oranında seyreltildi ve sonra nemli bir bölme içerisinde $57^{\circ} \mathrm{C}$ 'deki inkübatörde bırakıldı. Kesitler her biri 5 dakikalık sürelerde üç kez PBS ile yıkandı bunu takiben biyotinlenmiş sekonder antikor (histostain plus peroxidase kit, Zymed Laboratories Inc., South San Francisco, CA, USA) ile inkübe edildi ve daha sonra streptavidin, PBS içerisindeki horse radish peroksidaz ve 3,3- diaminobenzidin tetraklorid (DAB) ile 30 dakika konjuge edildi. Distile su ile yıkama sonrası, kesitler Mayer's Hematoksilen ile boyandı, dehidre edildi, ksilen ile temizlendi ve entellan ile kapatıldı. Kahverengi bir çökeltinin varlığı primer antikorlar için pozitif bulgu olarak gösterildi. Negatif kontrol örnekleri aynı işlemlere tabi tutuldu, primer antikorlar yerine benzer lg G'ler kullanıldı. Bütün kesitler Olympus C-5050 dijital kamera ile incelendi ve fotoğrafları çekildi. Yazılım programını (Image-Pro Express, Media-Cybernetics, Inc. Bethesda, MD, USA) çalıştıran bir bilgisayar sistemine bağlı Olympos BX51 mikroskop analizler için kullanıldı. İmmünoreaktivite desenleri iki araştırıcı tarafından bağımsız olarak değerlendirildi. Nükleer immün boyama bütün primer antikorlar için puanlandırıdı. Örneklerin grup ayrımından habersiz her iki araştırıcı her bir primer antikor için hayvan başına on farklı kesitten en az beş desen buldu. Preparatlar rastgele bir başlangıç ile sistematik olarak incelendi. 100 'lük büyütmedeki örnekleme preparatın en üst sağ köşesinden başladı ve yoğun şekilde immün reaktif hücreler analiz edildi.

\section{Bulgular}

Testis dokusu histolojik olarak incelendiğinde deneysel diyabete bağlı olarak seminifer tübülde germ hücre serilerinde kayıp, hücre bütünlüklerinde bozulma saptandı.

E-cadherin ekspresyonu incelendiğinde, deneysel diyabet grubunda (Şekil-1b) tüm hücre serilerinde $e$ cadherin ekspresyonunda azalma saptandı, diyabet grubuna uygulanan TK inhibitörü (Şekil-1c) tedavisi bu ekspresyonu arttırmayı başarmasına karşın ekspresyon düzeyleri kontrol grubu (Şekil-1a) ve kontrol+TK inhibitörü (Şekil-1d) grubu düzeylerine ulaşamamış olarak bulundu.

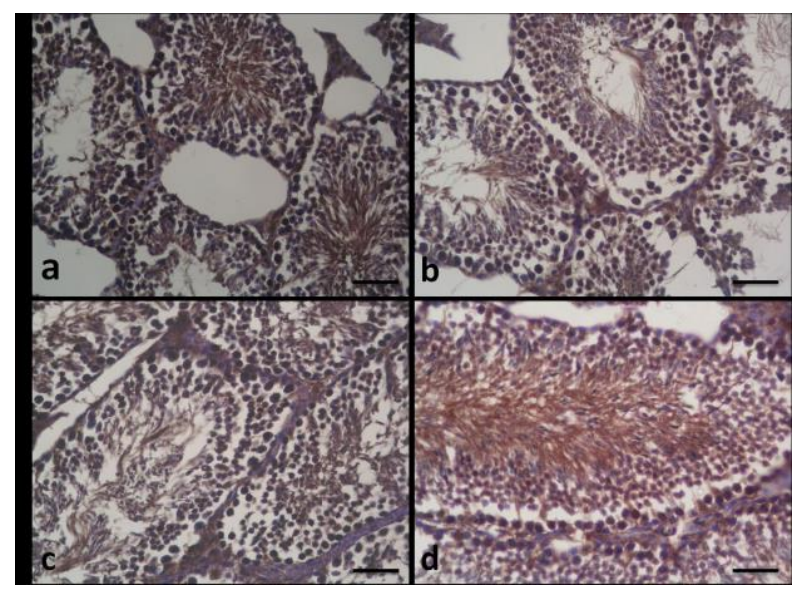

Şekil-1.e-cadherin a. Grup 1, kontrol grubu, b. Grup 3, diyabet+SF grubu, c. Grup 4, diyabet+TK inhibitörü grubu, d. Grup 2, TK inhibitörü grubu.

SSEA-1 ekspresyonu incelendiğinde, deneysel diyabet grubunda (Şekil-2b) SSEA-1 ekspresyonunda azalma 
saptandı, diyabet grubuna uygulanan TK inhibitörü (Şekil-2c) tedavisinin bu ekspresyonu oldukça fazla düzeyde arttırdığı izlendi. Kontrol grubu (Şekil-2a) ve kontrol+TK inhibitörü (Şekil-2d) grubu SSEA-1 ekspresyonu düzeyleri diyabet grubundan fazla, diyabet+TK inhibitörü uygulanan gruptan daha az olarak bulundu.

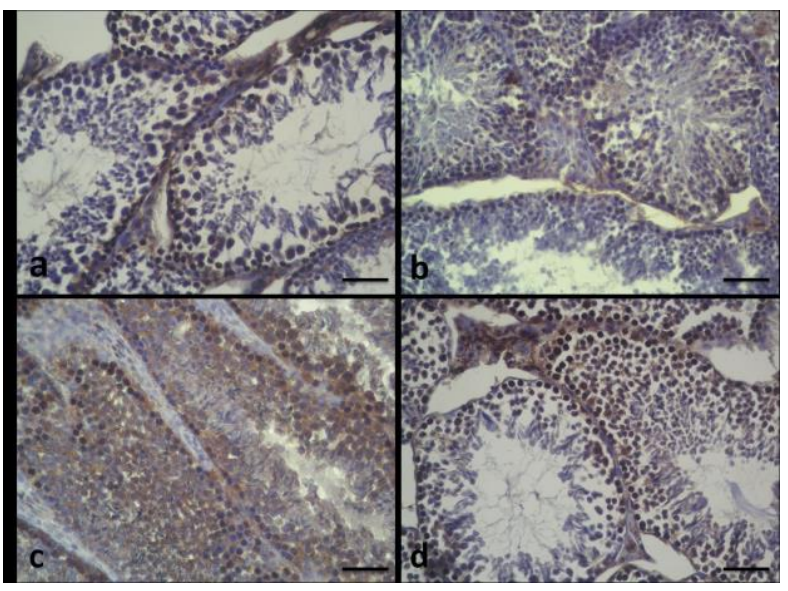

Şekil-2. SSEA-1 a. Grup 1, kontrol grubu, b. Grup 3 diyabet+SF grubu, c. Grup 4, diyabet+TK inhibitörü grubu, d. Grup 2, TK inhibitörü grubu.

\section{Istatistiksel Analiz}

Tek yönlü varyans analizi (ANOVA) testi sonuçlarına göre e-cadherin ve SSEA-1 immünohistokimyasal boyaması yapılan her bir guruptan randomize seçilmiş 10 testis örneğinden, seminifer tübül içerisindeki pozitif boyanan germ hücreleri analiz edildi. E-cadherin için diyabet grubu ile diyabet+TK, kontrol ve TK grupları arasındaki fark istatistiksel olarak anlamlı bulundu $(p<0.001)$ (Şekil-3). SSEA-1 için de diyabet grubu ile diyabet+TK, kontrol ve kontrol+TK grupları arasındaki fark ile, kontrol ve TK grupları ile diyabet+TK grubu arasındaki fark istatistiksel olarak anlamı bulundu her ikisi için de $p<0.001$ ) (Şekil-4). Kontrol ve TK grupları arasında ise her iki boyama için istatistiksel olarak anlamlı fark yoktu $(p>0.05)$.

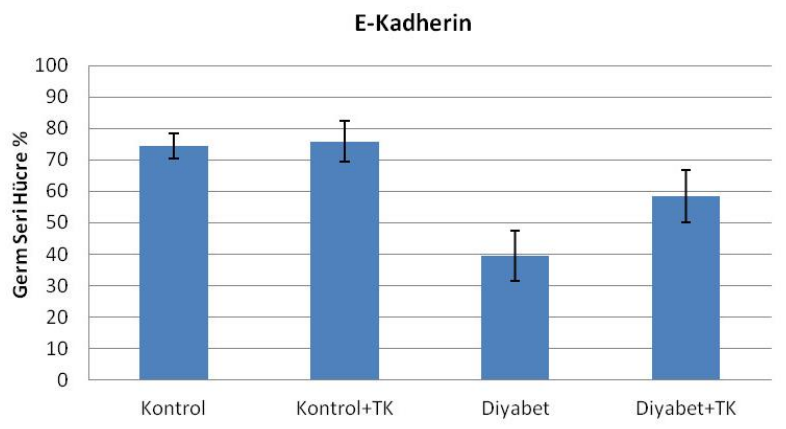

Şekil-3. E- cadherin istatistiksel analizi.

\section{Tartışma}

Çalışmamızda bir tirozin kinaz inhibitörü olan sunitinib kullanımına bağlı deneysel diyabet modelinde testis dokusu üzerine olan değişikliklerin, hücre adezyonu ve pluripotensi kapasitesi açısından incelenmesi amaç edinilmiştir.

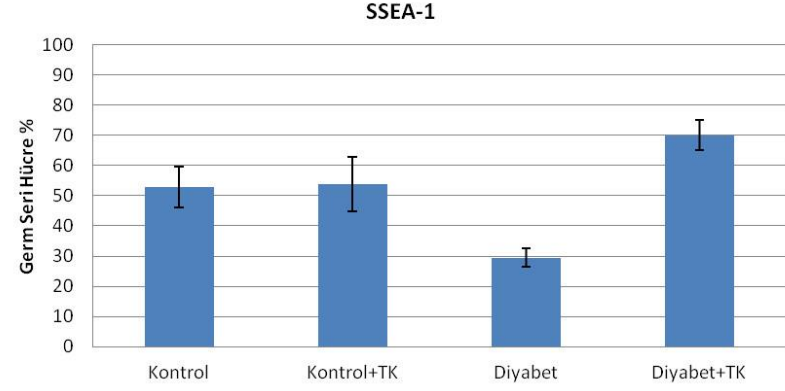

Şekil-4. SSEA-1 istatistiksel analizi

Bir TK inhibitörü olan sunitinib, hücresel sinyali, çoklu RTK yolaklarını hedefleyerek durdurur. Bunlar tümör anjiyogenez ve tümör proliferasyonunda rol alan tüm paletlerden türetilmiş büyüme faktörleri, plateletderived growth factor (PDGF-Rs) ve vasküler endotel büyüme faktör reseptörlerini, vascular endothelial growth factor receptors (VEGFRs) kapsamaktadır. Sunitinib, ayrıca, RTK olan CD-117'yi (c-KIT) inhibe eder ki, CD- 117 uygun olmayan mutasyon ile aktifleştirildiğinde gastrointestinal stromal hücre tümörlerini aktive eder (13). Öte taraftan sunitinib böbrek kanseri için ilk basamak tedavidir. Sunitinib'in, diğer TK inhibitörleriyle birlikte tip 2 diyabette ve yeni başlangıçlı tip 1 diyabette kan şekerini düşürdüğü bildirilmiştir (14). Sunitinib kullanımıyla insülin gereksinimlerinde azalma ile diyabet kontrolünde iyileşme saptanmıştır. Ancak, glikoz seviyelerini düşürme açısından sunitinib etki mekanizması üzerine fikir birliği yoktur (15).

Yaptığımız bu çalışmada, bir TK inhibitörü olan sunitinib'in diyabet hastalarında, hücre adezyon molekülleri özelinde, e- cadherin ve hücre pluripotensi ile farklılaşması özelinde SSEA-1 üzerinden nasıl bir etki mekanizması oluşturacağı araştırılmıştır. Elde edilen veriler sonucunda diyabet guruplarında $e$ cadherin ekspresyonunun, kontrol guruplarına oranla daha az olduğu saptanmıştır. Diyabetin testiste, hem germ hücrelerinin kendi aralarında hem de destek hücreleri ile aralarında olan hücre adezyon davranışlarında hasarlanmaya yol açtığı düşünülmektedir. Diyabet grubuna tedavi amaçlı sunitinib uygulanması, istatistiksel anlamlı olmayan düzeyde e-cadherin ekspresyonunun artışına yol açmaktadır. 
Öte yandan, SSEA-1 ekspresyonu diyabet grubunda kontrol gurubuna oranla anlamlı oranda düşük bulunmuş, bu gruba sunitinib uygulanması kontrol gurubundan da daha yüksek bir SSEA-1 ekspresyonuna yol açmıştır. SSEA-1'in ekspresyonunun artışı, hücre farklanma sürecinde özellikle diyabetli grupta sunitinib uygulanımının, pluripotensi kapasitesini indüklediği ve diyabetli grupta tedavi sürecine katkı sağladığı düşünülmektedir.

\section{Sonuç}

Diyabetin testiste germ hücre serilerinde sayısal olarak azalmaya ve hücre adezyon mekanizmasında bozulmaya yol açtığı ve sunitinib uygulanmasının bu hasarlanmada tamir edici rol oynadığı düşünülmektedir. Oluşan hasarın tedavisinin başarısı, sunitinib dozu ve süresine bağıı olarak farklılık gösterebilmektedir. Gelecekte bu konuda yapılacak moleküler çalışmalar, soruna ışık tutabilecektir.

\section{Kaynaklar}

1. Lin Y, Sun Z. Current views on type 2 diabetes. J Endocrin 2010;204(1):1-11.

2. Harrison D, Griendling KK, Landmesser U, Hornig B, Drexler H. Role of oxidative stress in atherosclerosis. Am J Cardiol 2003;913A):7A-11A.

3. Stephens JW, Khanolkar MP, Bain SC. The biological relevance and measurement of plasma markers of oxidative stress in diabetes and cardiovascular disease. Atherosclerosis 2009;202(2):321-9.

4. La Vignera S, Calogero AE, Condorelli R, Lanzafame F, Giammusso B, Vicari E. Andrological characterization of the patient with diabetes mellitus. Minerva Endocrinol 2009;34(1):1-9

5. Mallidis C, Agbaje I, McClure N, Kliesch S. The influence of diabetes mellitus on male reproductive function: A poorly investigated aspect of male infertility. Urologe 2011;50(1):33-7.

6. Petroianu A, Alberti LR, Antonio M, deMelo B, de Almeida LM. Relation between diabetes mellitus and male fertility. Einstein 2009;7(4):407-10.

7. Young B, Heath JW. Wheater's Functional Histology, 4th edition, Churchill Livingstone; London: 2000.

8. Doğan AL, Güç D. Sinyal iletimi mekanizmaları ve kanser. Hacettepe Tıp Dergisi 2004;35(1):34-42.

9. Bhise SB, Nalawade AD, Wadhawa $\mathrm{H}$. Role of protein tyrosine kinase inhibitors in cancer therapeutics. Indian J Biochem Biophys 2004;41(6):273-80.

10. Hulpiau P, vanRoy F. Molecular evolution of the cadherin superfamily. Int J Biochem Cell Biol 2009;41(2):349-69.

11. Nakayama F, Nishihara S, Iwasaki H, et al. CD15 expression in mature granulocytes is determined by alpha 1,3fucosyltransferase IX, but in promyelocytes and monocytes by alpha 1,3-fucosyltransferase IV. J Biol Chem $2001 ; 276(19): 16100-6$.

12. Gomez R, Barros HM. Ethopharmacology of the antidepressant effect of clonazepam in diabetic rats. Pharmacol Biochem Behav 2000;66(2):329-35.

13. Hartmann JT, Kanz L. Sunitinib and periodic hair depigmentation due to temporary C-KIT inhibition. Arch Dermatol 2008;144(11):1525-6.

14. Quek R, George S. Gastrointestinal stromal tumor: A clinical overview. Hematol Oncol Clin North Am 2009;23(1):69-78.

15. Tyrrell HE, Pwint T. Sunitinib and improved diabetes control. BMJ Case Rep 2014;24:2014. 